\title{
The Effect of Internationalising the Student Community on Graduate Students' Global Citizenship: A Case from Uganda
}

\author{
Justin Ayebare and David Onen
}

\begin{abstract}
This article examines the effect of internationalising the student community on graduate students' demonstrated commitment to global citizenship at a university in Uganda. It arose from a sequential explanatory survey study. Quantitative and qualitative data were gathered from a sample of I80 graduate students, with the former analysed employing descriptive and inferential statistics, while the latter were analysed using thematic content analysis. The quantitative results revealed that an internationalised student community has a statistically significant positive effect on graduate students' demonstrated global competence, but not on their demonstrated commitment to social responsibility. The qualitative findings produced similar results. They revealed that the presence of international students on campus coupled with graduate students' participation in international activities such as conferences and inter-cultural activities promoted their commitment to global citizenship. These findings are in line with those of previous studies. We thus recommend that universities in Uganda and other developing countries in the Global South further internationalise their graduate student community as a strategy to promote their commitment to global citizenship.
\end{abstract}

Key words: internationalisation, global citizenship, globalisation, higher education, student community

Cet article examine l'effet de l'internationalisation de la communauté étudiante sur l'engagement démontré des étudiants diplômés en faveur

ABOUt THE AUTHORS: JUSTIN AYEBARE AND DAVID ONEN, Makerere University. Email: jusayebare@gmail.com 
de la citoyenneté mondiale dans une université en Ouganda. Elle est née d'une étude explicative séquentielle. Des données quantitatives et qualitatives ont été recueillies auprès d'un échantillon de I8o étudiants ayant reçu leur diplôme, les premiers analysés à l'aide de statistiques descriptives et inférentielles, et les derniers à l'aide d'analyses thématiques du contenu. Les résultats quantitatifs ont révélé qu'une communauté étudiante internationalisée a un effet positif statistiquement significatif sur la compétence mondiale démontrée des étudiants des cycles supérieurs, mais pas sur leur engagement démontré en matière de responsabilité sociale. Les observations qualitatives ont donné des résultats similaires. Ils ont révélé que la présence d'étudiants étrangers sur le campus, conjuguée à la participation des étudiants des cycles supérieurs à des activités internationales telles que des conférences et des activités interculturelles, a augmenté leur engagement en faveur de la citoyenneté mondiale. Ces observations sont conformes à celles des études précédentes. Nous recommandons donc que les universités ougandaises ainsi que celles des autres pays du Sud Global en voie de développement internationalisent davantage leurs communautés d'étudiants ayant reçu leur diplôme en tant que stratégie visant à promouvoir leur engagement en faveur de la citoyenneté mondiale.

Mots clés: internationalisation, citoyenneté mondiale, mondialisation, enseignement supérieur, communauté étudiante

\section{Introduction}

Globalisation has accelerated the flow of people, cultures, knowledge, and technologies across borders, enhancing inter-connectedness (Marginson, 20I0) in a world where developments in one place influence everybody's lives (Zahabioun, Yousefy, Yarmohammadian, and Keshtiaray, 20I3). Universities and their graduates have felt the impact of this phenomenon (Boni and Calabuig, 20I7). In order to live and work in a globalised world, graduates need to be aware of global realities, and to be inter-culturally responsive. One way to nurture such awareness is to expose students to multi-cultural contexts in which they can experience diverse beliefs, values, and perspectives. According to Jones (2013), this exposes students to intercultural learning both at home and abroad that enables them to become global citizens. The strategies adopted to achieve this objective vary from one context to another. The study on which this article in based explored the effect of internationalisation on graduate students' demonstrated commitment to global citizenship at a university in Uganda. The investigation was motivated by reported low levels of global citizenship among graduates in the country.

While the notion of global citizenship is not new, its framing as an edu- cational policy objective is fairly recent (Brigham, 20II). In ancient Greece, Socrates and his colleague, Diogenes, identified themselves as 'citizens of the world' and abhorred the practice of restricting an individual to his/her political community (Green, 20I2). However, some scholars saw this as a rebellion against citizenship of the traditional local authority (Schattle, 2009). Nonetheless, the desire to become global citizens grew among the citizens of Greece and other countries. Renaissance scholar Immanuel Kant wrote in his essay, Perpetual peace: A philosophical sketch, that "the peoples of the earth have entered to varying degrees into a universal community... to the point where a violation of rights in one part of the world is felt everywhere" (Schattle, 2009, p. 4). This line of thought was compounded by the atrocities of the two world wars, which culminated in a vigorous campaign for a more cosmopolitan model of global governance and the formation of the United Nations Organisation (UNO) in I945 to foster world peace and security (Schattle, 2009). By the I990s, the notion of global citizenship had gained traction in scholarly debates (Reade, Reckmeyer, Cabot, Jaehne, and Novak, 2013). While it has also been adopted as a key strategic principle by higher education institutions in many parts of the world (Schattle, 2009; Larsen, 20I4), little research has been conducted on how higher education students in developing countries are nurtured to become global citizens.

Universities have always had an international dimension that is manifested in the universality and borderless nature of the knowledge they produce and disseminate as well as the movement of scholars across the world (De Wit, Hunter, Howard and Egron-Polak, 20I5). However, these institutions' international activities expanded dramatically in volume and scope during the last two or three decades of the $20^{\text {th }}$ century (Altbach and Knight, 2007; Jones and De Wit, 2012). Framed as a strategic issue in higher education, internationalisation is part of the mission and vision of universities across the globe (De Wit, 20II). The extent to which the internationalisation of the student body impacts the sense of global citizenship among graduates has not yet been fully explored and understood, especially in developing countries where the internationalisation of higher education has not fully taken root.

The study drew on Mezirow's (I99I) transformative theory of learning, which holds that through an educational experience, people learn to negotiate unfamiliar situations, evaluate their values and those of others, and understand social complexities through developing tolerance and a commitment to social justice and equality. Mezirow argued that when people learn from one another, new values, beliefs, and meanings are often created or existing ones strengthened. We thus hypothesised that students' interaction with their international counterparts in various university activities 
has the potential to transform their knowledge and beliefs about humanity and the world.

This study was organised around three key concepts, namely, global citizenship, internationalisation of higher education, and internationalisation of the student community. According to Brigham (20II), global citizenship is an approach to understanding, seeing, and acting; a way of understanding how the world works in terms of the links between our lives and those of others; a way of seeing social justice and equity, other people's reality, diversity, and inter-connectedness, and the way that people can make a difference in others' lives. Morais and Ogden (20II) state that, global citizenship is a multi-dimensional concept, which refers to the way by which one exercises one's social responsibility, global competence, and global civic engagement. This conceptualisation was adopted in this study.

Morais and Ogden (20II) describe social responsibility as the individual's concern for others and for the environment in which people live. Socially responsible students thus evaluate social issues and identify with efforts to address global injustice. Such students also respect diverse perspectives on local and global issues while promoting an ethos of social service that recognises the inter-connectedness between local behaviours and their global consequences. The study thus examined students' awareness of their social responsibility, sense of global justice and altruism, and empathy. Global competence means having an open mind that actively seeks to understand other people's cultural norms and expectations (Morais and Ogden, 20II). Therefore, globally competent students recognise their strengths and limitations in engaging in inter-cultural encounters; demonstrate an array of inter-cultural communication skills; can successfully engage in inter-cultural encounters, and show an interest in global issues and events. Finally, global civic engagement refers to individuals and groups' predisposition to respond to local, national and global community issues through volunteerism, political activism, and community participation (Morais and Ogden, 20II). The study thus investigated graduate students' involvement in civic activities as well as local civic activism.

De Wit et al. (2015, cited in Teferra, 20I9) define internationalisation of higher education as the "intentional process of integrating an international, inter-cultural or global dimension into the purpose, functions, and delivery of post-secondary education, to enhance the quality of education and research for all students and staff, and to make a meaningful contribution to society". However, scholars such as Teferra (20I9) argue that the process of internationalising African higher education may not be as 'intentional' as De Wit and his co-authors suggest. According to Gao (2OI5), the internationalisation of higher education is a multi-dimensional concept that concerns different aspects of higher education delivery including gover- nance and organisational support, the student community, academic staff, curriculum, and research and community engagement.

Our study focused on investigating the effect of internationalising the student community on the global citizenship of graduate students at Makerere University in Uganda. According to Gao (20I5) and Spencer-Oatey and Dauber (20I7), internationalisation of the student community refers to campus programmes and activities that bring local and foreign students together. This produces a culturally diverse student body, which enriches inter-cultural interaction and integration (Spencer-Oatey and Dauber, 20I7). The study thus analysed the internationalisation of the student community in terms of international/foreign (from outside Uganda) students and domestic/local/national (from within Uganda) students' joint participation in activities like international internships, workshops, conferences, and joint national and international orientation programmes.

The study site is a premier university in Uganda with several international students and an international student office. As part of its quest to become a globally competitive institution, the university adopted a comprehensive internationalisation strategy a few years ago. Among other things, the strategy aims to attract international students. It is held that this will contribute to students' development as global citizens by drawing synergies between international and inter-cultural contexts and between local and global responses to issues and events. However, the university has yet to achieve this goal. According to the Inter-University Council for East Africa (IUCEA) (2OI4), Ugandan graduates have low capacity to live and work in the region. This could be due to their lack of inter-cultural and international knowledge, which limits their competence. Furthermore, a recent study (Kanyeheyo, 20I5) concluded that the country's graduates demonstrate lower levels of civic engagement than their Kenyan counterparts. This could also be attributed to low levels of global citizenship despite the mechanisms adopted by stakeholders to internationalise universities.

This study aimed to explore the effect of internationalising the student community on graduate students' demonstrated commitment to global citizenship at Makerere University in Uganda. It thus investigated the effect of internationalising the student community on graduate students' demonstrated (i) commitment to social responsibility, (ii) global competence, and (iii) commitment to global civic engagement. 


\section{Literature Review}

Several scholars have investigated the relationship between the internationalisation of the student community and students' global citizenship (see e.g., Denson and Zhang, 20I0; Lilley, Barker and Harris, 20I5; Harrison and Peacock, 20I3). However, most of these studies focused on countries in the Global North such as the United Kingdom, the United States, and other Western developed countries. There is a paucity of research on this issue in developing countries in the Global South, especially in Africa. Furthermore, previous studies on an internationalised student community and global citizenship have produced contradictory findings.

For example, Jooste and Heleta (20I6) reached the radical conclusion that the notion of global citizenship in higher education was simply irrelevant for university students in the Global South. The authors asserted that higher education institutions in developing countries need to be pragmatic and prepare their students for the 'real world' rather than equipping them with skills to work anywhere in the world - especially in countries in the Global North. Indeed, they stated that such countries should not waste time and resources chasing after "vague rhetoric and popular buzzwords" (20I6, p. 8) like global citizenship. After all, the cultures, values, and norms currently promoted by proponents of global citizenship are products of Western ideologies and an intellectual orientation intended to sustain cultural imperialism and Western supremacy (Calhoun, 2003, cited in Jooste and Heleta, 20I6). Bourn (20II) also criticised the notion of using an internationalised student community to boost students' global citizenship on the grounds that the concept mainly serves the interests of students from northern institutions who are able to move freely between institutions and become more globally aware, acquire inter-cultural skills, and learn other languages.

In contrast, Spencer-Oatey and Dauber (20I7) contend that higher education institutions in both contexts would benefit from a diverse student body. Firstly, an internationalised student community would enable students to learn from multiple cultures and societies, which enriches their inter-cultural interaction, integration, and engagement while studying. Schapper and Mayson (2004) concur that a student who lives and studies in an internationalised student community learns a great deal about different cultures and tolerance.

Denson and Zhang's (2010) survey of 5,464 graduate students in Australia concluded that interaction with diverse cultures in various activities on campus promoted appreciation of, and respect for, diversity. The authors thus recommended that higher education institutions play a more active role in fostering inter-cultural interaction amongst students from all backgrounds. Lilley (2013) interviewed international key informants to explore what becoming and being a global citizen meant in the contemporary university. She found that an internationalised university setting leads to significant transformation in terms of global mindedness, self-realisation, and personal friendships as local students engage with their international counterparts.

Other scholars have identified factors that may hinder students from participating in inter-cultural and international activities on campus. Lunn (2008) noted that high tuition and visa fees hinder the recruitment, retention, and support of some overseas students, particularly from Africa. Killick (20I2) also observed that students might withdraw to the comfort of familiar communities even when their student body is internationalised. Green (2005) found that low levels of interest in and participation by students in on- and off-campus international activities resulted in low levels of global citizenship. According to the author, reluctance to participate in these activities could be due to cultural differences such as language, bias, and threats to the academic success and group identity of different students in the university. In this regard, Harrison and Peacock (20I3) asserted that, "Home students perceive threats to their academic success and group identity from the presence of international students on the campus and in the classroom... leading to a 'passive xenophobia' for the majority" (p. 877).

Studies on the internationalisation of the student community in Africa include Sehoole and De Wit's (20I4) research that observed that the internationalisation of higher education on the continent has followed the same pattern as that in other parts of the world, especially Europe and North America. They added that this has meant that African universities and students have reaped few benefits from the process. It is on this basis that Teferra (20I4) suggested that African higher education institutions should adopt new approaches to internationalisation, particularly those that would lead to increased regional and South-South cooperation, and build on the social responsibility and civic engagement aspects of higher education. These diverse views motivated the current investigation.

\section{Methodology}

The mixed-methods study employed a sequential explanatory research design to enable deeper understanding of the issues under investigation. Quantitative data were gathered from a sample of I80 graduate students across the university using a stratified random sampling technique based on Biglan's (I973) classification of university academic fields. This classification resulted in four college/school strata, namely: the hard-pure, hard-applied, soft-pure, and soft-applied, and two department strata, i.e., life and non-life departments. A self-administered questionnaire was 
employed that was tested in advance for its validity and reliability. The questionnaire contained the following indices: internationalisation of the student community (IoSC - II items, $\alpha=0.79$ ), social responsibility (SR - I5 items, $\alpha=0.90$ ), global competence (GCo - I2 items, $\alpha=0.89$ ), and global civic engagement (GCE - I7 items, $\alpha=0.83$ ). Based on Cronbach's coefficients (cited in Bakkabulindi, 20II), the questionnaire was considered to be reliable as the alpha coefficients were all above 0.5 . All the items except the background ones in the questionnaire were continuous and were scaled on a five-point Likert scale ranging from: $\mathrm{I}=$ Strongly Disagree (SD) to $5=$ Strongly Agree (SA). Thus, a higher score indicated higher levels of the construct in question. The data were analysed using descriptive and inferential statistics.

The qualitative data were collected by means of interviews with seven graduate students who were randomly selected from among those who had completed the questionnaire. The initial intention was to interview one student from each of the eight departments from the four sampled colleges. However, due to factors beyond our control, we were only able to interview seven. The interviews lasted between 40 and 60 minutes. For the sake of anonymity, these students were assigned codes based on their college/ department, disciplinary category, and gender; hence, a hard-pure, nonlife systems male was assigned HPNLSM; a hard-applied non-life systems female, HANLSF; hard-applied, life systems male, HALSM; soft-pure nonlife systems female, SPNLSF; and soft-pure life systems female SPLSF. The interview data were analysed inductively using thematic content analysis. This enabled us to understand the meaning in the complex data through the development of summary codes.

\section{Results}

4.1 Respondents' Characteristics

In line with the university's enrolment data, male respondents (Io9 or $60 \%$ ) dominated the sample. In terms of disciplinary fields, the majority of the participants were drawn from the soft-applied (59 or $32.8 \%$ ) disciplines, followed by the hard-applied (49 or $27.2 \%$ ); soft-pure (4I or $22.8 \%$ ) and hard-pure $(25$ or $17.2 \%)$ disciplines. This trend was also in line with the enrolment distribution of graduate students in the different colleges, with more students enrolled in humanities and social sciences programmes than in the pure sciences. Local students dominated the sample (I54 or $85.6 \%$ ), with 26 (I4.4\%) international students. Finally, the majority of the respondents (II2 or $62.3 \%$ ) had never travelled abroad. Their prior exposure to international issues was therefore likely to be limited and any change in their commitment to global citizenship could be attributable to their international experiences while at university. Three of the seven participants who were interviewed were male and four were female while five were local and two were international students. The number of interviewees was dictated by the small sample size and the limited number of international students enrolled in the selected departments.

4.2 Findings on Internationalisation of the Student Community (IoSC) The respondents were asked to indicate their level of agreement/disagreement with II statements that measured the IoSC. The descriptive results are summarised in Table I.

Table 1. Descriptive Statistics on the Internationalisation of the Student Community (IoSC)

\begin{tabular}{|l|c|l|l|}
\hline Items on loSC & Mean & Std. dev & Interpretation \\
\hline Some students at my University are from outside Uganda. & 4.70 & .644 & Agree \\
\hline $\begin{array}{l}\text { At my university, students are encouraged to do their } \\
\text { internship outside Uganda. }\end{array}$ & 2.63 & .995 & Not sure \\
\hline $\begin{array}{l}\text { I have participated in an international workshop/ } \\
\text { conference. }\end{array}$ & 4.40 & .595 & Agree \\
\hline We hold regular inter-cultural festivals at my University. & 3.81 & .968 & Agree \\
\hline $\begin{array}{l}\text { At my University, orientation programs target students from } \\
\text { different countries. }\end{array}$ & 3.82 & .908 & Agree \\
\hline $\begin{array}{l}\text { At my University, students from different countries are } \\
\text { allowed to form clubs and associations. }\end{array}$ & 4.15 & .656 & Agree \\
\hline $\begin{array}{l}\text { At my University, students from different countries are } \\
\text { encouraged to join different clubs. }\end{array}$ & 4.13 & .638 & Agree \\
\hline The University provides funding for student organizations. & 3.20 & .857 & Not sure \\
\hline At my University, halls of residence are open to all students. & 4.14 & .742 & Agree \\
\hline $\begin{array}{l}\text { My University has an office for coordinating cross-border } \\
\text { student activities. }\end{array}$ & 4.06 & .774 & Agree \\
\hline $\begin{array}{l}\text { My University provides opportunities for students from } \\
\text { different countries to participate in volunteer programs. }\end{array}$ & 4.05 & .690 & Agree \\
\hline
\end{tabular}

Overall mean $=3.91$ (Agree)

The results in Table I show a favourable rating of the IoSC by graduate students at the university with an overall mean response rate of 3.9I which corresponded to Agree on the Likert scale. The majority of the respondents agreed with all except two items (At my University, students are encouraged to do their internship outside Uganda; and the University provides funding for student organisations to sponsor cross-border activities), with more or 
less similar standard deviations. This suggests that the respondents rated the IoSC at the university relatively 'high'.

The qualitative findings revealed that across the disciplinary categories, the IoSC manifested in the presence of international students on campus, availability of student associations/clubs or societies, holding of international conferences, projects or workshops, and hosting of inter-cultural activities on campus.

Presence of International Students. The interviewees confirmed that there were several international students, but that the numbers were dwindling. They reported that they had lived, studied, or interacted with international students, mainly from Rwanda, Kenya, Nigeria, Democratic Republic of Congo, Sudan, Japan, and Norway.

Associations/clubs or Societies. Scholars generally agree that student associations and clubs are an important element of an institution's attempts to internationalise because they provide a platform for interaction among students from different cultural backgrounds. Five participants agreed that such associations existed at the university. One said:

There are both academic and non-academic societies in our university. I am a member of the University Petroleum and Geology Society, which brings together students from different countries and cultural backgrounds within our department. The Society enables us to socialise as well as hold meetings, seminars, and workshops. These help in sharing learning experiences about disciplines related to Petroleum and Geology (HPNLSM).

Similarly, HALSM noted that there are different associations at the university where students from various nationalities, cultures, and disciplines interact and share their experiences about institutional, national, and global issues. However, as observed by SPNLSF, some of these associations attract students with homogenous characteristics, which could hinder multi-cultural interaction.

International Conferences, Projects, or Workshops. Three of the participants shared their experience of interacting with students from different cultural backgrounds at international conferences, projects, or workshops and said that this enabled them to become familiar with the values, practices, and perspectives of others. According to HALSM:

I have participated in many international conferences - especially those that have been organised in Uganda. In these conferences, I have met and interacted with international students from different countries. I have also been working on some projects with interna- tional students. For example, I am currently attached to a project that has a Japanese student. [Thus], I have worked, lived, and socialised with international students ..

Inter-cultural Activities on Campus. Intercultural activities or events provide an opportunity for students of different cultures or nationalities to interact. These include cultural galas, volunteer activities, other social activities and platforms, and accommodation. Four participants said that they took part in such activities on campus and recognised their importance in promoting inter-cultural and global learning. One remarked: "The University is open to volunteer activities. There are no restrictions but we are encouraged to support e.g. blood, cash, and material donations, and these are usually organised by students" (HANLSF). In similar vein, HALSM revealed that the University allows the organisers of activities like the Mobile Telecommunication Network (MTN) run to solicit support from students. This event raises funds to support vulnerable mothers and blood donations and many students participate.

4.3 Findings on Global Citizenship (GC)

The study examined GC in terms of graduate students' demonstrated commitment to global social responsibility (GSR) (I5 items), global competence (GCo) (I2 items), and global civic engagement (GCE) (I7 items). The respondents were asked to express their agreement/disagreement with several items measuring GC using a five-point Likert scale ranging from Strongly Disagree (coded as I) to Strongly Agree (coded as 5). Table 2 presents the descriptive results on graduate students' GSR. 
Table 2. Graduate Students' Demonstrated Commitment to Global Social Responsibility (GSR)

\begin{tabular}{|c|c|c|c|c|}
\hline $\begin{array}{l}\text { Dimension on } \\
\text { GSR }\end{array}$ & Items on GSR & Mean & Std. dev & Interpretation \\
\hline \multirow[t]{5}{*}{$\begin{array}{l}\text { Awareness of } \\
\text { responsibility }\end{array}$} & $\begin{array}{l}\text { It is my responsibility to be involved in } \\
\text { global issues. }\end{array}$ & 4.23 & .610 & Agree \\
\hline & $\begin{array}{l}\text { It is my responsibility to understand } \\
\text { cultural differences. }\end{array}$ & 4.16 & .638 & Agree \\
\hline & $\begin{array}{l}\text { It is my responsibility to respect cultural } \\
\text { differences. }\end{array}$ & 4.23 & .570 & Agree \\
\hline & $\begin{array}{l}\text { I would like to join groups that } \\
\text { emphasize knowing people from } \\
\text { different countries. }\end{array}$ & 4.08 & .716 & Agree \\
\hline & $\begin{array}{l}\text { I am interested in learning about other } \\
\text { cultures. }\end{array}$ & 4.20 & .638 & Agree \\
\hline \multirow[t]{5}{*}{ Global Justice } & $\begin{array}{l}\text { People around the world should get what } \\
\text { they are entitled to have. }\end{array}$ & 4.23 & .796 & Agree \\
\hline & $\begin{array}{l}\text { Well-off countries should help the less } \\
\text { fortunate. }\end{array}$ & 4.17 & .810 & Agree \\
\hline & $\begin{array}{l}\text { Basic social services should be availed to } \\
\text { everyone wherever they live. }\end{array}$ & 4.43 & .678 & Agree \\
\hline & $\begin{array}{l}\text { It is never necessary to use force against } \\
\text { others. }\end{array}$ & 4.17 & 1.04 & Agree \\
\hline & $\begin{array}{l}\text { No one country or group should } \\
\text { dominate others. }\end{array}$ & 4.29 & .859 & Agree \\
\hline \multirow[t]{5}{*}{$\begin{array}{l}\text { Altruism and } \\
\text { Empathy }\end{array}$} & $\begin{array}{l}\text { I can empathize with people from other } \\
\text { countries. }\end{array}$ & 4.11 & .834 & Agree \\
\hline & $\begin{array}{l}\text { It is easy to put myself in someone else's } \\
\text { shoes. }\end{array}$ & 4.06 & .859 & Agree \\
\hline & $\begin{array}{l}\text { I am concerned about the rights of all } \\
\text { people around the world. }\end{array}$ & 4.29 & .657 & Agree \\
\hline & $\begin{array}{l}\text { I respect the rights of all people around } \\
\text { the world. }\end{array}$ & 4.33 & .617 & Agree \\
\hline & $\begin{array}{l}\text { The needs of the world's most fragile } \\
\text { people are more pressing than my own. }\end{array}$ & 3.92 & .948 & Agree \\
\hline
\end{tabular}

Overall mean $=4.20$ (Agree)
Table 2 shows that the majority of the respondents agreed with all the items on GSR, with an overall mean response rate of 4.20 that corresponds with Agree on the Likert-scale used with more or less similar standard deviations. This suggests that they rated their commitment to GSR as high.

Table 3 presents a summary of the descriptive results on graduate students' GCo.

Table 3. Graduate Students' Demonstrated Global Competence (GCo)

\begin{tabular}{|c|c|c|c|c|}
\hline $\begin{array}{l}\text { Dimension on } \\
\text { GCo }\end{array}$ & Item on GCo & Mean & Std. dev & Interpretation \\
\hline \multirow[t]{4}{*}{ Self-Awareness } & $\begin{array}{l}\text { I am confident that I can thrive in any } \\
\text { cultural setting or country. }\end{array}$ & 3.90 & .809 & Agree \\
\hline & $\begin{array}{l}\text { I know how to help in solving some of } \\
\text { the global problems. }\end{array}$ & 3.93 & .763 & Agree \\
\hline & $\begin{array}{l}\text { I know several ways in which I can make } \\
\text { a difference in the world. }\end{array}$ & 3.80 & .813 & Agree \\
\hline & $\begin{array}{l}\text { I can get other people to care about } \\
\text { global problems. }\end{array}$ & 3.69 & .899 & Agree \\
\hline \multirow[t]{4}{*}{$\begin{array}{l}\text { Inter-cultural } \\
\text { Communication }\end{array}$} & $\begin{array}{l}\text { I often adapt my communication style to } \\
\text { the traditions of others. }\end{array}$ & 3.93 & .819 & Agree \\
\hline & $\begin{array}{l}\text { I can communicate with people from } \\
\text { different cultures. }\end{array}$ & 3.81 & .895 & Agree \\
\hline & $\begin{array}{l}\text { I can mediate interactions between } \\
\text { people of different cultures. }\end{array}$ & 3.77 & .836 & Agree \\
\hline & $\begin{array}{l}\text { I am fluent in more than one } \\
\text { internationally used language. }\end{array}$ & 2.91 & 1.183 & Not sure \\
\hline \multirow[t]{4}{*}{$\begin{array}{l}\text { Global } \\
\text { Awareness }\end{array}$} & $\begin{array}{l}\text { I am informed about current issues that } \\
\text { impact relationships between countries. }\end{array}$ & 3.77 & .891 & Agree \\
\hline & $\begin{array}{l}\text { I understand how the various cultures of } \\
\text { this world interact. }\end{array}$ & 3.62 & .928 & Agree \\
\hline & $\begin{array}{l}\text { I am aware that I am connected to } \\
\text { people in other countries. }\end{array}$ & 4.00 & .851 & Agree \\
\hline & $\begin{array}{l}\text { My actions in my local environment may } \\
\text { affect people in other countries }\end{array}$ & 4.10 & .789 & Agree \\
\hline
\end{tabular}

Overall mean $=3.77$ (Agree) 
The results show that, with the exception of one item (fluency in international languages), the respondents favourably rated graduate students' GCo, with an overall mean response rate of 3.77, which corresponds with Agree on the Likert scale used, and more or less similar standard deviations. This suggests that they rated their demonstrated GCo as 'high'.

The third and last dimension of GC was graduate students' GCE. Table 4 summarises the descriptive results.

Table 4 illustrates that the respondents favourably rated graduate students' GCE at the university with an overall mean response rate of 4.08 that corresponds with Agree on the Likert scale used, and more or less similar standard deviations. This suggests that they rated their demonstrated commitment to GCE as high.

These quantitative results were collaborated by the qualitative findings from the interviews with seven graduate students from different departments. Overall, the interviews revealed that students' interaction with others from diverse cultural backgrounds in various campus activities enhanced their commitment to GC. They observed that internationalisation of the student community enhanced their GC in seven major ways, namely, improving their friendships and acceptance; empathy; a sense of global justice; self-awareness; global awareness; civic engagement; and inter-cultural communication.
Table 4. Graduate Students' Demonstrated Commitment to Global Civic Engagement (GCE)

\begin{tabular}{|c|c|c|c|c|}
\hline $\begin{array}{l}\text { Dimension } \\
\text { on GCE }\end{array}$ & Items on GCE & Mean & Std. dev & Interpretation \\
\hline \multirow{7}{*}{$\begin{array}{l}\text { Involvement } \\
\text { in Civic } \\
\text { Activities }\end{array}$} & $\begin{array}{l}\text { I would be happy to do voluntary work to } \\
\text { help individuals abroad. }\end{array}$ & 4.17 & .704 & Agree \\
\hline & $\begin{array}{l}\text { I would participate in a walk or run in } \\
\text { support of a global cause. }\end{array}$ & 4.13 & .753 & Agree \\
\hline & $\begin{array}{l}\text { I would feel comfortable to make a cash } \\
\text { donation for a charity abroad. }\end{array}$ & 4.04 & .789 & Agree \\
\hline & $\begin{array}{l}\text { I would feel comfortable getting employment } \\
\text { with humanitarian organizations abroad. }\end{array}$ & 4.30 & .672 & Agree \\
\hline & $\begin{array}{l}\text { I would feel happy to help people who are in } \\
\text { difficulty abroad. }\end{array}$ & 4.25 & .661 & Agree \\
\hline & $\begin{array}{l}\text { I would work informally with a group } \\
\text { towards solving a global humanitarian } \\
\text { problem. }\end{array}$ & 4.21 & .749 & Agree \\
\hline & $\begin{array}{l}\text { I would write an opinion letter to the local } \\
\text { media expressing my concerns over global } \\
\text { issues. }\end{array}$ & 3.92 & .724 & Agree \\
\hline \multirow[t]{5}{*}{$\begin{array}{l}\text { Political } \\
\text { Voice }\end{array}$} & $\begin{array}{l}\text { I feel confident to express my concerns } \\
\text { about world problems in the media. }\end{array}$ & 4.00 & .751 & Agree \\
\hline & $\begin{array}{l}\text { I feel confident to contact someone in } \\
\text { government on global concerns. }\end{array}$ & 3.91 & .818 & Agree \\
\hline & $\begin{array}{l}\text { I feel confident to participate in campus } \\
\text { events that express their views about global } \\
\text { problems. }\end{array}$ & 4.04 & .699 & Agree \\
\hline & $\begin{array}{l}\text { I feel confident to display posters that } \\
\text { promote a just world. }\end{array}$ & 3.97 & .810 & Agree \\
\hline & $\begin{array}{l}\text { I would comfortably sign a petition in } \\
\text { support of a just world. }\end{array}$ & 4.02 & .853 & Agree \\
\hline \multirow[t]{5}{*}{$\begin{array}{l}\text { Global Civic } \\
\text { Activism }\end{array}$} & $\begin{array}{l}\text { Where possible, I always buy locally } \\
\text { produced products. }\end{array}$ & 4.04 & .993 & Agree \\
\hline & $\begin{array}{l}\text { I deliberately buy products that never exploit } \\
\text { marginalized people. }\end{array}$ & 4.15 & .851 & Agree \\
\hline & $\begin{array}{l}\text { I would boycott products that harm people } \\
\text { anywhere in the world. }\end{array}$ & 4.14 & 1.020 & Agree \\
\hline & I attend community social activities. & 4.08 & .880 & Agree \\
\hline & $\begin{array}{l}\text { I discuss international issues with other } \\
\text { people. }\end{array}$ & 3.94 & .940 & Agree \\
\hline
\end{tabular}

Overall mean $=4.08$ (Agree) 
Friendships and Acceptance. The participants stated that the internationalisation of the student community was vital in changing their relationships with others and that interacting with students from diverse cultural backgrounds enabled them to become more understanding, tolerant, and appreciative of other cultural values and beliefs. Some observed that such interaction made them value the uniqueness and life experiences of other students. For instance, one commented:

I think, sometimes, we have this wrong assumption about other people or their cultures. However, when we closely interact with them, our perceptions of them often change. I used to think that the people who come from ... [name of the country withheld by the researchers] were primitive and backward, yet that is not true. I have discovered that in the course of interacting with such people here on campus (HALSM).

According to HANLSF, interacting with students from different cultural backgrounds made it possible for her to understand, accept, and make friends with them:

As you interact with students from other countries, you come to understand and know how they embrace different things. You also get to understand what they mean when they talk about their countries and their lives. You will come to appreciate why they say or do things the way they do.

These insights offer food for thought and are worth exploring in more detail and in other contexts.

Empathy. Some participants acknowledged that internationalising the student community made them feel more compassionate towards other people. HANLSF shared that:

Sometimes, when you listen to issues from different parts of the world, you come to sympathise with people coming from some regions ...At times, you feel like you should do something to contribute towards improving their situation because today it might be theirs but tomorrow, it might be yours!

Although only seven students were interviewed, their insights suggest that a multi-cultural student community could act as fertile ground for them to acquire empathy. This also requires further investigation.

Global Justice. Four of the participants revealed that their inter-cultural campus experiences made them identify with and promote justice while respecting everyone's rights. HPNLSM observed: "I am no longer living as a true ... [nationality withheld], but one in a global community. While we are constantly fighting back at home, here we respect each other as students belonging to the same university". HALSM commented: "We are all human beings who experience the human pain...We, therefore, deserve to receive the same treatment wherever we are", while HANLSF said, "We must learn to respect the ideas, values, rights, and practices of others, while they respect my rights too". Although the findings are not generalisable, these insights suggest that the interactions that occur in an internationalised student community create an environment where students learn to place a high premium on justice. This issue is also worthy of further investigation.

Self-awareness. Some participants said that interacting with students from different backgrounds and other countries made them more confident about living and working away from home. HALSM said:

I have lived with students from other countries and they have helped me to have a better picture of what their countries look like... I believe that I can now easily live and work outside Uganda. This was not the case before.

Global Awareness. Participants reported that studying in an internationalised student community enabled them to gain global knowledge and awareness about what takes place in different parts of the world. HANLSF observed that "when you interact with people from different cultural backgrounds, you get to know about different aspects of life.... they share their different experiences and you get to know about different things in the world". SPLSF said:

One could gain awareness about international issues not only from

the courses he/she is taught but also by interacting with international students when they share what happens in their home countries. In so doing, they provide first-hand international and inter-cultural understanding about their countries, which may not be written anywhere.

Although not generalisable, these insights suggest that the interactions that occur in an internationalised student community enable students to gain global knowledge and awareness. This could also be the subject of further research.

Civic Engagement. Some study participants acknowledged that studying in an internationalised student community developed their interest in participating in community activities. HALSM remarked:

I have been encouraged by different students to participate in demonstrations, protests, and petitions urging the university to make some changes - especially on some policies that hurt us, students. Some of those who encouraged me to participate in these activities are foreign students. 
For this particular interviewee, his interaction with students from other countries has enabled him to not only learn to be active at the civic level, but also to act on issues that affect others.

Inter-cultural Communication. Participants revealed that they honed their communication skills through being involved in different inter-cultural student activities. HPNLSM, a male international student reported that he learned to speak some local languages because he stayed and closely interacted with local fellow students: "I can now greet in Luganda, Swahili, and Kinyarwanda. I did not know all these languages before". Another student observed:

I have learned how the Baganda [a tribe in Uganda] passionately preserve their culture. I have seen how people from other cultural backgrounds here suddenly switch to their local languages when a need arises. This has forced me to learn other people's languages.

However, some graduate students we interviewed said they did not have time to engage in campus activities. SANLSM said, "For me at the graduate level, I have limited time for university activities that are non-academic .... I often come, study, do my course work, and leave...to go and attend to my work elsewhere". While this issue requires further investigation, it would appear that graduate students that live and study in an internationalised student community develop inter-cultural communication if they socialise with those from different backgrounds.

\subsection{Testing the Null Hypotheses}

Based on the literature review and the study's objectives, the following null hypotheses were derived and tested using simple and multiple linear regression analysis:

$\mathrm{HO}_{\mathrm{I}}$ : Internationalising the student community (IoSC) has no significant effect on graduate students' demonstrated commitment to social responsibility (SR).

$\mathrm{HO}_{2}$ : Internationalising the student community has no significant effect on graduate students' demonstrated global competence (GCo);

$\mathrm{HO}_{3}$ : Internationalising the student community has no significant effect on graduate students' demonstrated commitment to global civic engagement (GCE); and

$\mathrm{HO}_{4}$ : Internationalising the student community has no significant effect on graduate students' demonstrated global citizenship (GC).

Table 5 presents the results of the test of the hypotheses.
Table 5. Regression Results on Different Dimensions of GC Versus IoSC

\begin{tabular}{|l|l|l|l|}
\hline Dimensions & R2 & Beta ( $\beta$ ) & P \\
\hline Demonstrated commitment to SR versus loSC & 0.004 & 0.061 & 0.426 \\
\hline Demonstrated GCo versus loSC & 0.043 & 0.269 & 0.005 \\
\hline Demonstrated commitment to GCE versus loSC & 0.039 & 0.208 & 0.008 \\
\hline Demonstrated commitment to GC (Overall) versus loSC & 0.041 & 0.202 & 0.007 \\
\hline
\end{tabular}

The results showed that, firstly, there was a positive relationship between IoSC and the graduate students' commitment to each aspect of GC (all betas were positive - GSR: $\beta=0.06 \mathrm{I}$; GCo: $\beta=0.269$; and GCE: $\beta=0.208$ ). Secondly, internationalising the student community had a significant positive effect on all except one dimension (GSR: $\mathrm{R}^{2}=0.004, \mathrm{p}=0.426>0.05$ ) of the GC of graduate students (GCo: $\mathrm{R}^{2}=0.043, \mathrm{p}=0.005<0.05: \mathrm{GCE}: \mathrm{R}^{2}=$ $0.039, p=0.008<0.05)$. Therefore, all the null hypotheses, except the one that states "internationalising the student community has no significant effect on graduate students' demonstrated commitment to social responsibility" - were rejected and their corresponding hypotheses were accepted. Overall, internationalising the student community was found to have a significant positive effect on graduate students' demonstrated commitment to GC $\left(R^{2}=0.04\right.$ I, $\left.p=0.007<0.05\right)$.

\section{Discussion}

This study explored the effect of internationalising the student community (IoSC) on three dimensions of GC, namely, GSR, GCo and GCE. Our central thesis was that studying in an internationalised student community has a positive and significant effect on graduate students' demonstrated commitment to GC (i.e., GSR, GCo, and GCE) in its totality. Although national and institutional realities may have a bearing on students' overall campus experience, in the context of this study, the results indicate that internationalising the student community positively and significantly affected the graduate students' demonstrated commitment to GC in its totality. However, internationalising the student community positively and significantly affected graduate students' GCo and GCE, but not GSR.

First, the findings showed that internationalising the student community had a significant positive effect on their demonstrated commitment to GC. The participants demonstrated an awareness and understanding of their GSR, expressed in values such as an increased sense of global justice, altruism and empathy; GCo - self-awareness, global awareness, and intercultural communication; and a commitment to GCE - involvement in civic activities and political activism. This finding is in line with the notion that these three dimensions are crucial in determining the GC 
of graduate students (Morais and Ogden, 20II; Noddings, 2005). It also confirms Killick's (2OI2) conclusion that when university students live and study with students from foreign and other local cultural backgrounds, it helps them to become global citizens that are knowledgeable about global issues. However, such a community must be culturally balanced and well managed if it is to lead to the effective development of the global citizenship of individual students.

This finding calls for a re-examination of Jooste and Heleta's (20I6) position that discourages countries in the Global South from devoting time and resources to pursue students' global citizenship through internationalisation. In the context of this study, we argue that, if well planned, internationalising the student community could be very beneficial to both students and institutions. We concur with Teferra's (20I4) call for the strengthening of social responsibility and civic engagement in African higher education. Whether or not internationalisation in Africa largely follows what is happening in Europe and North America (Sehoole and De Wit, 20I4), it can still significantly benefit students, especially in the area of global citizenship, enabling them to become more globally aware, acquire inter-cultural skills, and learn other languages like their northern counterparts.

Second, the finding that internationalising the student community had no significant effect on graduate students' demonstrated commitment to GSR was somewhat unexpected. This could be attributed to the uniqueness of this study's context of a university in Uganda, a developing country where little emphasis has been placed on internationalising student communities, and, as expressed by one participant, where students may not have the time and interest to participate in inter-cultural activities on campus. While some scholars have argued that global citizenship is a notion that is only intended to benefit students from the North (Bourn, 2OII) and is an intellectual orientation that aims to sustain cultural imperialism and Western supremacy (Calhoun, 2003, cited in Jooste and Heleta, 2016), studies conducted in developed countries (e.g., Green, 2005; Harrison and Peacock, 20I3) also point to low levels of interest among students in participating in on- and off-campus activities. Internationalisation of their student community may thus not enhance their GC. We attribute graduate students' low levels of interest in such activities to Ugandan students' heavy academic and personal workloads. This finding is therefore not in tandem with Mezirow's theoretical stance, which posits that new values and beliefs are often created or existing ones are strengthened through an educational experience in an internationalised student community. Although this finding did not support those of earlier scholars like Coryell et al. (20I4), it concurs with Harrison and Peacock's (2013) study that con- cluded that cultural diversity stimulated new inter-cultural understanding among students.

Third, the study showed that internationalising the student community significantly affected the graduate students' demonstrated GCo. Graduate students in different disciplinary fields noted that they were aware of global realities; could live and work in unfamiliar contexts and environments; and had acquired inter-cultural communication skills and understanding. This finding is in line with Mezirow's theoretical stance, which posits that new values, beliefs, and meanings are created or existing ones are strengthened through an educational experience gained in an internationalised student community. It also concurs with those of earlier studies like Lilley (2013) who concluded that the changes occurring in universities and across world are enhancing the development of student global mindedness. Killick (20I2) noted that modern students' increased interaction with the global community is not only enhancing their knowledge of the world but also affecting their sense of self in the world. All these factors could be contributing to the development of and commitment to global citizenship among both graduate and undergraduate university students.

Finally, we found that internationalising the student community significantly affected graduate students' GCE. Across the disciplinary fields, participants demonstrated an increased sense of civic engagement and political activism. This was attributed to their participation in community activities that positively impact humanity. They mentioned volunteer activities such as blood, cash, and material donations, which according to HPNLSM broke the 'I can't help tendency' among students. Platforms like demonstrations, protests and petitions helped the students to develop 'a spirit to act to change the world'. This finding supports and validates Mezirow's (Iو9I) theoretical claim that new values, beliefs, and meanings are created or existing ones are strengthened through an educational experience gained in an internationalised student community. It also corroborates the work of earlier researchers like Hendershot and Sperandio (2009) and Killick (20I2) who concluded that an educational experience in an internationalised student community promoted global citizenship. They argued that this would encourage students to take action to offer communities assistance from an altruistic rather than an egotistical personal stance. Overall, the study validated the notion that internationalising the student community has a significant impact on university students' GC.

\section{Conclusion and Recommendations}

Based on the study's findings, we conclude that internationalising the student community - at least in the context of a specific university in Uganda - has no significant effect on graduate students' demonstrated 
commitment to global social responsibility, but has a positive significant effect on their global competence and global civic engagement. Overall, we found that internationalising the student community had a positive significant effect on graduate students' global citizenship, other factors notwithstanding. This implies that for graduate students to become global citizens, they should live and study under enabling circumstances, whether locally or abroad. The enabling circumstances identified in this study included a student body with international students, with students participating in international conferences or projects, clubs and associations, and inter-cultural activities on campus. These are believed to have facilitated the graduate students' change in mindset, promoting friendships and acceptance, empathy, a sense of global justice, self-awareness, global awareness, civic engagement, and inter-cultural communication.

In light of this, we recommend that managers in Ugandan and other universities foster positive inter-cultural interaction amongst students at all levels through the admission of international students, and encourage and support international activities like international conferences, projects, or workshops, and inter-cultural activities.

Understanding how internationalising the student community contributes to students' commitment to global citizenship requires an understanding of the broader institutional internationalisation culture of the community of students. Seen in this light, Morais and Ogden's (20II) conceptualisation that we adopted in this study might not fully explain global citizenship in all contexts. This study fills this gap by extending the model to include friendships and acceptance in the social responsibility dimension of global citizenship. We established that becoming more understanding, tolerant, accepting, and appreciative of other cultural values and beliefs was, in part, prompted by the diversity that participants were exposed to while on campus. Thus, global citizenship in the context of Uganda is a reflection of the overall student experience of diversity on campus. This research therefore adds to the current international research literature on global citizenship.

Although the pragmatic nature of this study could allow for partial generalisation of the findings, we acknowledge that our qualitative findings are perceptual, and are based on the views of a few graduate students drawn from a single university in Uganda. There is thus is a need for further research in this field to solicit the views of more students, especially undergraduates, and other stakeholders such as administrators in other institutions or countries.

\section{References}

Altbach, P. G., and Knight, J. (2007). The internationalization of higher education: motivations and realities. Journal of Studies in International Education 11(3/4), 290-305.doi: Io.II77/I0283I5307303542.

Bakkabulindi, F. E. K. (2OII). Perceived characteristics as correlates of use of ICT in Makerere University. Journal of Sociology and Education in Africa 10(I), I-I4.

Biglan, A. (I973). Relationship between subject matter characteristics and the structure and outputs of university departments. Journal of Applied Psychology 57(3), 204-213.

Boni, A., and Calbuig, C. (20I7). Education for global citizens at universities: Potentialities of formal and informal learning spaces to foster cosmopolitanism. Journal of Studies in International Education 21 (I), 22-38. doi:Io.II77/I0283I53I5602926.

Bourn, D. (20II). From internationalization to global perspectives. Higher Education Research and Development 30(5), 559-571. doi: 10.1080/0729 4360.2011 .598447$.

Brigham, M. (20II). Creating a global citizen and assessing outcomes. Journal of Global Citizenship and Equity Education 1(I), I5.

Coryell, E. J., Spencer, J.B., and Sehin, O. (20I4). Cosmopolitan adult education and global citizenship: perceptions from the European itinerant graduate professional study abroad program. Adult Education Quarterly 62 (92), I45-I64. doi:Io.II77/074I7136I35I5067.

De Wit, H. (20II). Globalization and internationalization of higher education. Revista de Universidad y Sociedad del Conocimiento (RUSC) 8(2), 24I-248.

De Wit, H., Hunter, F., Howard. L. and Egron-Polak. E. (2015). Internationalization of higher education. Brussels, Belgium: European Parliament.

Denson, N., and Zhang, S. (2010). The impact of student experiences with diversity on developing graduate attributes. Studies in Higher Education 35(5), 529-543. doi: 10.1080/03075070903222658.

Gao, Y. (2OI5). Towards a set of internationally applicable indicators for measuring university internationalization performance. Journal of Studies in International Education 19(2) I82-200. doi: I0.II77/IO28315314559030

Green, M. F. (2005). Internationalization of US higher education: The student perspective. Washington, DC: American Council on Education.

Green, M. F. (20I2). Global citizenship: what are we talking about and why does it matter? International Educator 21(3), I24-I27.

Harrison, N., and Peacock, N. (2013). Cultural distance, mindfulness, and passive xenophobia: Using integrated threat theory to explore home higher education students' perspectives on internationalization at home. British Educational Research Journal 36(6) 877-902. doi: Io.I080/OI4II920903I9I047. 
Hendershot, K., and Sperandio, J. (2009). Study abroad and the development of global citizenship identity and cosmopolitan ideals in undergraduates. Current Issues in Comparative Education 12(I), 45-55.

IUCEA. (20I4). Report from a study establishing the status of higher education qualifications systems and their contributions to higher education development in East Africa. Kampala, Uganda: Author.

Jones, E. (2013). Internationalization and student learning outcomes. In: De Wit, H. (ed.) An introduction to higher education internationalization. Center for higher education internationalization (CHEI): V \& P.

Jones, E., and De Wit, H. (20I2). Globalization of internationalization: Thematic and regional reflections on a traditional concept. AUDEM: The International Journal of Higher Education and Democracy 3(I), 35-54.

Jooste, N., and Heleta, S. (2016). Global citizenship versus globally competent graduates: A critical view from the South. Journal of Studies in International Education 21(I), 39-5I. doi: I0.II77/I0283153I663734I

Kanyeheyo, M. I. (20I5, November I9). The crippling dilemma of graduate youth unemployment. The New Vision. Accessed on: https://www. newvision.co.ug/new_vision/news/I3I9320/crippling-dilemmagraduate-youth-unemployment.

Killick, D. (20I2). Seeing ourselves in the world: Developing global citizenship through international mobility and campus community. Journal of Studies in International Education 16(4), 372-379. doi: IO.II77/IO2831531I431893.

Knight, J. (2008). Higher education in turmoil: The changing world of internationalization. Rotterdam, Netherlands: Sense Publishers.

Larsen, A. M. (20I4). Critical global citizenship and international service learning: A case study of the intensification effect. Journal of Global Citizenship and Equity in Education 4(I), 23-65.

Lilley, K., Barker, M., and Harris, N. (20I5). Exploring the process of global citizen learning and the student mindset. Journal of Studies in International Education 19(3), 225-245. doi:IO.II77/IO283153I4547822.

Lilley. C. (20I3). Exploring what being and becoming a global citizen means in contemporary universities: International key informants and mobility students' perspective. Doctoral dissertation, The University of Griffith. Retrieved from http://www.researchgate.net/publication/274712950.

Lunn, J. (2008). Global perspectives in higher education: Taking the agenda forward in the United Kingdom. Journal of Studies in International Education 12(3), 23I-254. doi: IO.II77/IO283I5307308332.

Marginson, S. (20I0). Higher education in the global knowledge economy. Procedia Social and Behavioral Sciences 2, 6962-6980.

Mezirow, J. (I99I). Transformative dimensions of adult learning. San Francisco, CA: Jossey Bass.
Morais, D., and Ogden, A. (20II). Initial development and validation of the global citizenship scale. Journal of Studies in International Education 15(5), I-23. doi:I0.II77/IO283I53I0375308.

Noddings, N. (Ed.). (2005). Educating citizens for global awareness. New York (NY): Teachers College Press.

Reade, C., Reckmeyer, W., Cabot, M., Jaehne, D., and Novak, M. (20I3). Educating global citizens for the $2 \mathrm{I}^{\text {st }}$ century. Journal of Corporate Citizenship 49, I00-II6

Schapper, J., and Mayson, S. (2004). Internationalization of the curriculum: an alternative to the Taylorization of academic work. Journal of Higher Education Policy and Management 26(2), I89-205. doi:Io.Io80/ I360080042000218258.

Schattle, H. (2009). Global citizenship in Theory and Practice. In: R. Lewin (ed.) The handbook of practice and research in study abroad: Higher education and the quest for global citizenship, pp. 3-8. New York: Routledge.

Sehoole, C., and De Wit, H. (2OI4). Regionalization, internationalization and globalization of African higher education. International Journal of African Higher Education 1(I), 2I7- 24I. doi: https://doi.org/Io.6oI7/ ijahe.viii. 5648

Spencer-Oatey, H. and Dauber, D. (20I7) Internationalization and the development of 'global graduates': Hearing the students' voices. Global PAD Working papers. Available at Global PAD Open House http://www. warwick.ac.uk/globalpadintercultural.

Teferra, D. (20I4). Charting African higher education: Perspectives at a glance. International Journal of African Higher Education 1(I), 9-2I.

Teferra, D. (2019). Defining internationalization in higher education for society. In: Uwe Brandenburg, Hans De Wit, Elspeth Jones and Betty Leask. University World News. Downloaded on 20/09/20I9 fromhttps:// www.universityworldnews.com/post.php? story=20190626135618704

Zahabioun, S., Yousefy, A., Yarmohammadian, H. M., and Keshtiaray, N. (20I3). Global citizenship education and its implications for curriculum goals at the age of globalization. International Education Studies 6(I), I95-206. doi:I0.5539/ies.v6nipi95. 
